\title{
Press-On Force Effect on the Efficiency of Composite Restorations Final Polishing-Preliminary In Vitro Study
}

\author{
Anna Lehmann ${ }^{1}$, Kacper Nijakowski ${ }^{1, *,+}{ }^{+}$, Natalia Potempa ${ }^{1,+}$, Paweł Sieradzki ${ }^{2}$, Mateusz Król ${ }^{2}$, Olaf Czyż ${ }^{3}$, \\ Agnieszka Radziszewska ${ }^{3}$ and Anna Surdacka ${ }^{1}$ (D) \\ 1 Department of Conservative Dentistry and Endodontics, Poznan University of Medical Sciences, \\ 60-812 Poznan, Poland; annalehmann@ump.edu.pl (A.L.); nataliapotempa@ump.edu.pl (N.P.); \\ annasurd@ump.edu.pl (A.S.) \\ 2 Student's Scientific Group, Department of Conservative Dentistry and Endodontics, Poznan University of \\ Medical Sciences, 60-812 Poznan, Poland; pawel.sier12@gmail.com (P.S.); mateuszkrol1996@gmail.com (M.K.) \\ 3 Department of Surface Engineering and Material Characterisation, AGH University of Science \\ and Technology, 30-059 Cracow, Poland; olafczyz@agh.edu.pl (O.C.); radzisze@agh.edu.pl (A.R.) \\ * Correspondence: kacpernijakowski@ump.edu.pl \\ + These authors contributed equally to this work.
}

\section{check for} updates

Citation: Lehmann, A.; Nijakowski, K.; Potempa, N.; Sieradzki, P.; Król, M.; Czyż, O.; Radziszewska, A.; Surdacka, A. Press-On Force Effect on the Efficiency of Composite Restorations Final PolishingPreliminary In Vitro Study. Coatings 2021, 11, 705. https://doi.org/ 10.3390/coatings11060705

Academic Editors: Devis Bellucci and James Kit-hon Tsoi

Received: 3 May 2021

Accepted: 9 June 2021

Published: 11 June 2021

Publisher's Note: MDPI stays neutral with regard to jurisdictional claims in published maps and institutional affiliations.

Copyright: (c) 2021 by the authors. Licensee MDPI, Basel, Switzerland. This article is an open access article distributed under the terms and conditions of the Creative Commons Attribution (CC BY) license (https:// creativecommons.org/licenses/by/ $4.0 /)$.
Abstract: The surface texture of dental restorations has a major influence on plaque accumulation and aesthetical appearance. The study aimed to evaluate the surface roughness of composite resins depending on the varying polishing sequences and applied forces. A total of 60 samples from two composite resins (Boston and Charisma) were polymerized using a lamp with $1200 \mathrm{~mW} / \mathrm{cm}^{2}$ intensity and covering celluloid strip. The polishing sequence consisted of $12.6 \mathrm{~mm}$ OptiDisc (Kerr) with increased disc per each subsequent step. Half of the samples were polished at $1 \mathrm{~N}$ force, with the other half at $2 \mathrm{~N}$. The surface roughness examination was performed using a WYKO NT930 (Veeco) optical profilometer. The selected roughness parameters were compared by ANOVA with the significance level $\alpha=0.05$. The more complex polishing sequence affected on the composite smoothness. Higher roughness was identified in Charisma samples as compared to Boston. The specimens polished with $2 \mathrm{~N}$ force contained a slightly rougher surface than those polished with $1 \mathrm{~N}$. However, these differences were not statistically significant. Despite the satisfactory visual effect obtained by polishing the composite samples, the profilometric examination revealed the roughness. Finishing is crucial for providing a smooth composite surface, allowing it to function properly in the oral environment.

Keywords: composite resins; polishing; press-on force; profilometry; surface roughness

\section{Introduction}

The discovery and introduction to the widespread use of composite fillings have led to a real revolution in dentistry. In addition to many advantages, this material has several drawbacks. Many researchers point to its low resistance to oral conditions, in addition to deliberation on possible carcinogenic effects of resin on soft tissues [1-3]. Furthermore, it is also a sensitive material to the technique of work. When creating a composite fill, it is necessary to consider many clinical factors, analyze indications and contraindications and work very carefully such that the final effect is satisfactory.

One of the factors influencing the more prolonged survival of composites is the polishing technique [4]. The exact procedure for finishing the filling allows for a smooth surface minimizing the risk of bacterial plate adhesion [5,6]. In an age of continuous rush of the doctor and the patient, the final and equally decisive stage is sometimes shortened or even ignored. An ideal situation would consist of a composite reconstruction of the tooth, which does not require correction, excess removal, or be touched with a drill. Such reconstructions are still very rare and require a great deal of knowledge, skills and 
experience. Most dentists adjust the filling to bite conditions after direct reconstruction. Optimal results are achieved by using carbide drill bits, smoothy cutting the surface of the composite [7-9]. However, diamond-coated burs are more popular among dentists due to their ease of use, low price and a broad range of available shapes. However, their work depends on the abrasion of composite layers. Accumulation of bacterial plaque into rough material is responsible for the formation of secondary caries and as a consequence of numerous complications from the pulp [10,11]. Incorrectly prepared composite fillings will require a replacement with a new filling, usually with larger examples. In this way, the tooth enters the filling exchange cycle, which usually ends with endodontic treatment or extraction [12].

Nowadays, various finishing and polishing systems are available on the market, including multi-stage systems consisting of two or more instruments and 'one-step' systems requiring only a solitary tool $[13,14]$. Depending on the type of material, the location and size of the filling, various finishing and polishing tools may be used, such as diamondcoated burs, carbide drill bits, polyurethane finishing and polishing discs, rubber caps impregnated with abrasive material, and polishing pastes [7,15]. Although the research does not explicitly indicate the advantage of any of the polishing systems $[14,16,17]$, these multi-stage discs of differing embankments remain very popular.

Many researchers have already analyzed the impact of different finishing and polishing procedures on the roughness of the composite filling, but a continuous update is needed. New materials and polishing systems requiring research analysis are still emerging. In addition, the literature indicates that dentists do not have sufficient knowledge of the pressure required for polishing [18]. Some polishing system manufacturers recommend using a force of $2 \mathrm{~N}$ or lower $[18,19]$, but dentists find it difficult to assess whether they are working properly.

In the study, a profilometric analysis was used to assess the polishing effect of individual discs and the pressure force. According to the literature, the clinically acceptable roughness of the filling after polishing should not be higher than $0.2 \mu \mathrm{m}$ to prevent plaque build-up and complications from the pulp [20,21].

The purpose of this study was to investigate the effect of pressure on individual components of a multi-stage system for finishing and polishing fillings from two different micro-hybrid composites. We asked the following hypotheses:

1. The increased press-on force affects the composite roughness.

2. The pressure force of $2 \mathrm{~N}$ is the most optimal for polishing.

3. The composite materials with different filler diameters require a different pressure force.

We will also try to answer whether it is possible to better educate dentists about using correct pressure forces of dental handpieces when polishing the filling.

\section{Materials and Methods}

\subsection{Materials Used in the Study}

In this in vitro study, two micro hybrid composite materials were used: Boston A2 (Arkona, Niemce, Poland) and Charisma A2 (Kulzer GmbH, Hanau, Germany). Detailed characteristics of the materials are presented in Table 1. 
Table 1. Characteristics of Composite Materials Used in the Study.

\begin{tabular}{|c|c|c|c|c|c|c|}
\hline $\begin{array}{c}\text { Material } \\
\text { (Manufacturer) }\end{array}$ & Type & Matrix & $\begin{array}{c}\text { Average } \\
\text { Particle Size }\end{array}$ & Filer Type & $\begin{array}{l}\text { Filer Loading } \\
\text { Vol \% }\end{array}$ & Shade \\
\hline $\begin{array}{l}\text { Boston (Arcona, } \\
\text { Niemce, Poland) }\end{array}$ & $\begin{array}{l}\text { microhybrid } \\
\text { composite }\end{array}$ & $\begin{array}{c}\text { organic Bis-GMA, } \\
\text { UDMA, Bis-Ema, } \\
\text { TEGDMA }\end{array}$ & $0.7-2 \mu \mathrm{m}$ & $\begin{array}{c}\text { Glass filler, } \\
\text { Ba-Al-Si, } \\
\text { Ba-Al-B-Si, silica }\end{array}$ & 78 & A2 \\
\hline $\begin{array}{l}\text { Charisma Classic } \\
\text { (Kulzer GmbH, } \\
\text { Hanau, Germany) }\end{array}$ & $\begin{array}{l}\text { microhybrid } \\
\text { composite }\end{array}$ & Bis-GMA & $0.005-10 \mu \mathrm{m}$ & $\begin{array}{c}\text { Glass filler, } \\
\text { Ba-Al-F, feldspar }\end{array}$ & 61 & $\mathrm{~A} 2$ \\
\hline
\end{tabular}

\subsection{Specimen Preparation}

One operator carried out all specimen preparation to reduce variability. In total, 60 specimens were prepared using $2 \mathrm{~mm}$-thick metal molds of $10 \mathrm{~mm}$ diameter. The uncured composites were inserted into the mold and intentionally overfilled. The mold was then sandwiched between transparent Mylar strips to expel excess material. Each disc was light-cured for $40 \mathrm{~s}$, from both sides, in accordance with the manufacturer's instructions (light intensity of $1200 \mathrm{~mW} / \mathrm{cm}^{2}$, Translux Wave, Kulzer GmbH, Hanau, Germany). Fortyeight samples were scratched, using a medium-thickness diamond bur $(40 \mu \mathrm{m})$ with a red code bar for finishing the filling (imitation of the bite adjustment procedure).

\subsection{Finishing Procedures}

The scratched samples were divided into two groups and polished with Kerr OptiDisc polishing system (Kerr, Bioggio, Switzerland), consisting of a 4-stage set with decreasing granularity of polishing surfaces: embankment $80 \mu \mathrm{m}$ (contour), $40 \mu \mathrm{m}$ (finish), $20 \mu \mathrm{m}$ (polish), $10 \mu \mathrm{m}$ (high gloss polish). The first group of samples was polished with a force of $1 \mathrm{~N}\left(\mathrm{n}_{1}=24\right)$ and the second group with a force of $2 \mathrm{~N}\left(\mathrm{n}_{2}=24\right)$. The force of pressure was controlled with axis fb5 (Axis, Gdansk, Poland) presented in Figure 1. Samples were mounted on top of the dynamometer and polished under its control. All polishing procedures were performed by a single investigator, using a low-speed handpiece rotating at 10,000 rpm in constant motion (KaVo, Biberach, Germany) without water refrigeration. The entire surfaces of the specimens were polished with each disc for $30 \mathrm{~s}$. A new polishing set of discs was used for every specimen. After finishing, all specimens were stored in distilled water and incubated at $37^{\circ} \mathrm{C}$ for seven days before the test procedures.

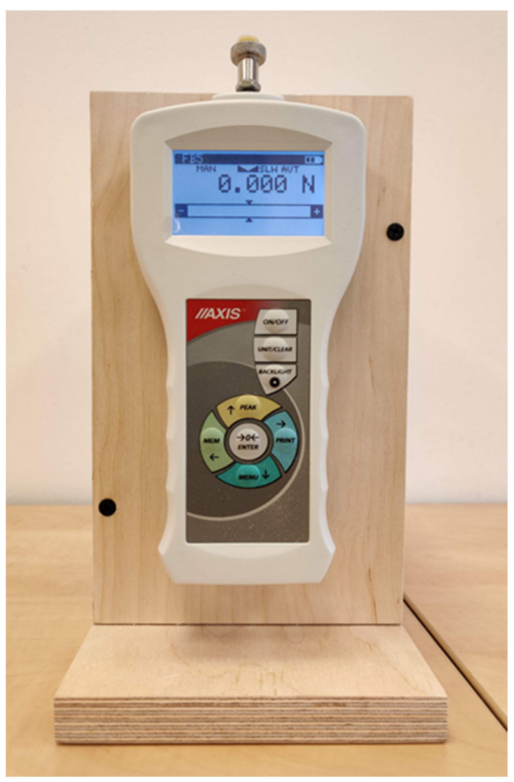

Figure 1. Force sensor used in the study. 


\subsection{Roughness Evaluation}

The measurement of surface roughness was carried out in the Department of Surface Engineering and Material Characterization, AGH University of Science and Technology, Cracow, Poland The reference point to the degree of polishing was 12 samples of a polymerized, non-contoured composite. Surface smoothness was assessed after each polishing step with a force of 1 and $2 \mathrm{~N}$. Each specimen was analyzed using an optical profilometer (Wyko NT930, Veeco, 85609 Aschheim/Dornach Munich, Germany) equipped with the inductive gauge stylus with a $2 \mu \mathrm{m}$ tip radius. The evaluated surface of each specimen was $1.17 \mathrm{~mm}^{2}$ in the central part of the sample. The tracing speed was $500 \mu \mathrm{m} / \mathrm{s}$.

The profilometric parameters included in the study:

- $\quad R_{a}$-arithmetic mean deviation of the profile from the mean line, measured along with the measuring or elementary section

- $R_{q}$-mean square deviation of the profile from the mean line along the measurement or elementary section

- $R_{z}$-roughness height from the mean line along the measuring or elementary section

- $R_{t}$-total profile height.

\subsection{Statistical Analysis}

These determined values were separately analyzed using a repeated-measures analysis of variance in the individual polishing steps $(40 \mu \mathrm{m}$ bur, OptiDisc $80,40,20+10 \mu \mathrm{m})$ depending on the composite resin (Charisma and Boston) and press-on force ( $1 \mathrm{~N}$ and $2 \mathrm{~N})$. The significance level was defined as $\alpha=0.05$.

\section{Results}

The representative figures for optical profilometry analysis in the individual polishing steps depending on the composite resin and the press-on force are presented in Table 2. The mean values of all determined profilometric parameters are shown in Table 3. There were no statistically significant differences between the individual steps of the polishing sequence irrespective of the press-on forces and the type of composite material (Table 4). However, some trends were observed in the changes of these parameters. Therefore, the parameter $R_{z}$ was chosen as a representative factor, and Figures 2-5 were made for the graphical interpretation.

In each sequence, the smoothest sample was the control (only light-cured). On the other hand, of the polishing samples, the smoothest surface had samples polished using the full set of polishing discs, and the roughest surface using only one disc with the highest grit. There were visible differences between successive samples in the polishing sequence but did not show statistical significance.

In a comparison of composite resins, Charisma was characterized by greater roughness than Boston. In turn, samples polished with less pressure were found to be less rough in texture. The samples made from Boston material were smoother with no discernible difference in polishing effect due to the higher press-on force. Moreover, Charisma specimens had a noticeable tendency to increase surface roughening when Sof-lex discs were used with higher press-on force.

However, the interaction of composite type and sequence and the interaction of polishing force and sequence for both materials did not have a statistically significant effect on the smoothness of the tested surfaces. 


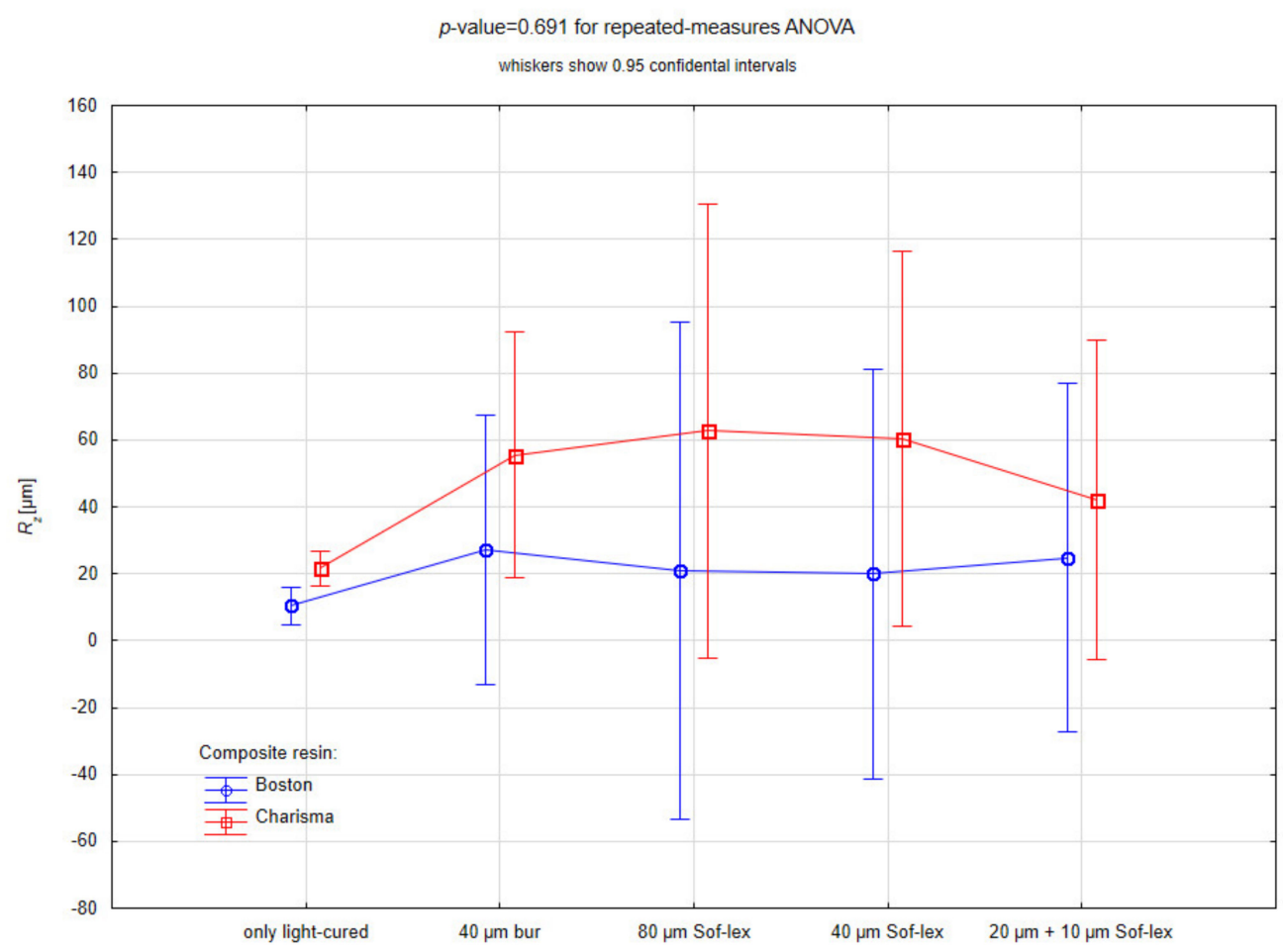

Figure 2. Repeated-measures analysis of variance for $R_{z}$ values in the individual polishing steps depending on the composite resin.

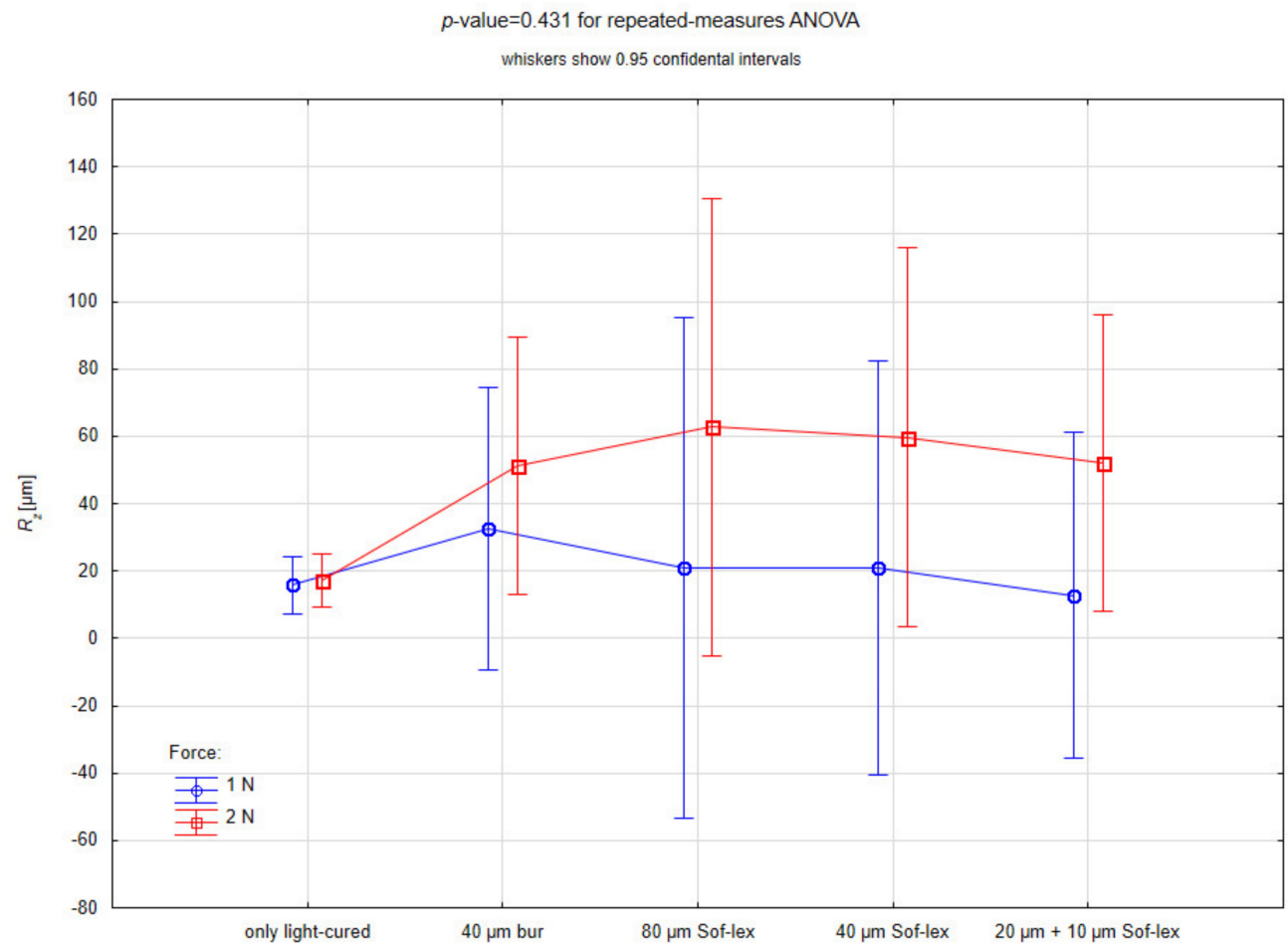

Figure 3. Repeated-measures analysis of variance for $R_{z}$ values in the individual polishing steps depending on the press-on force. 


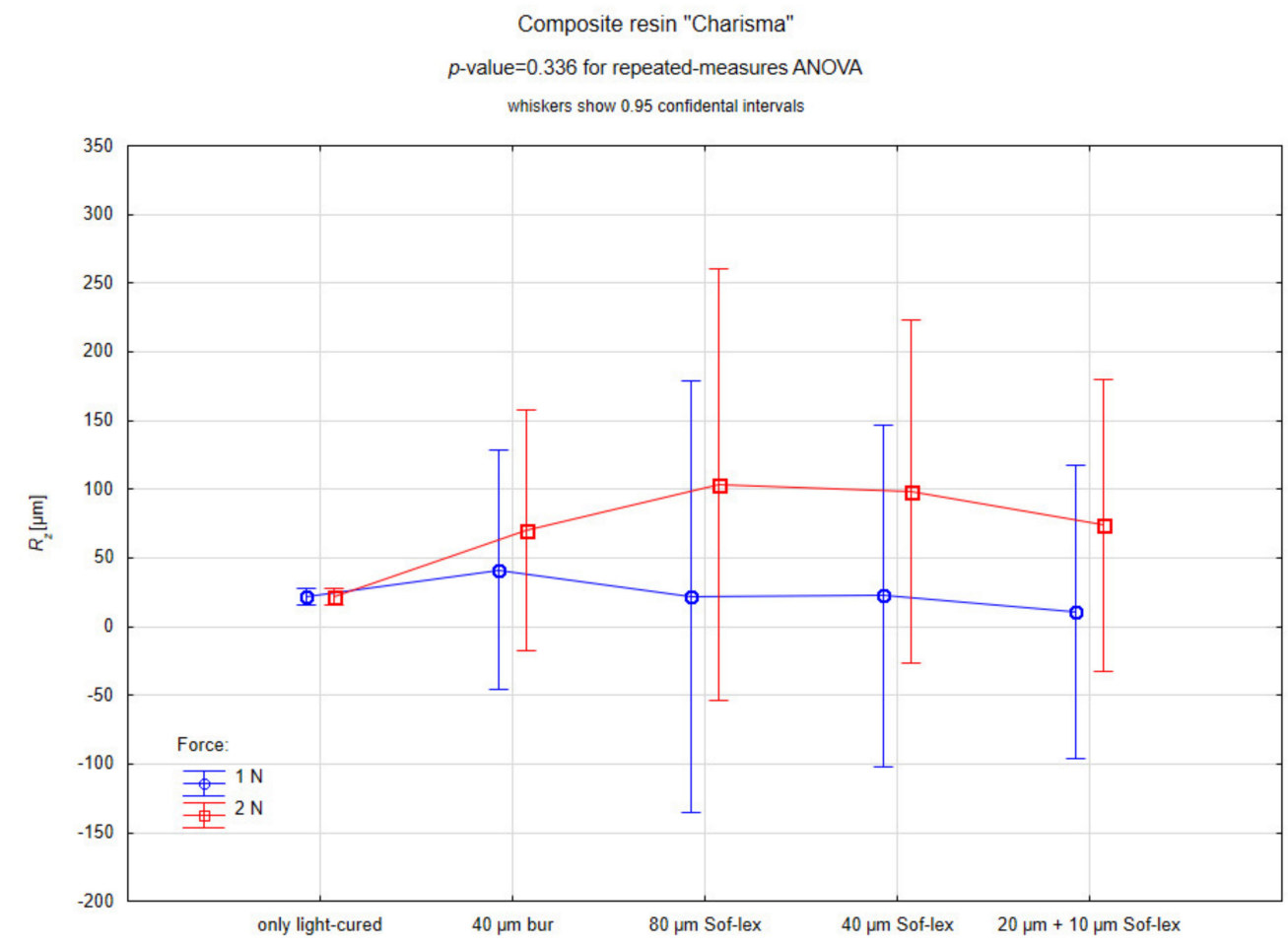

Figure 4. Repeated-measures analysis of variance for $R_{z}$ values in the individual polishing steps depending on the press-on force for Charisma samples.

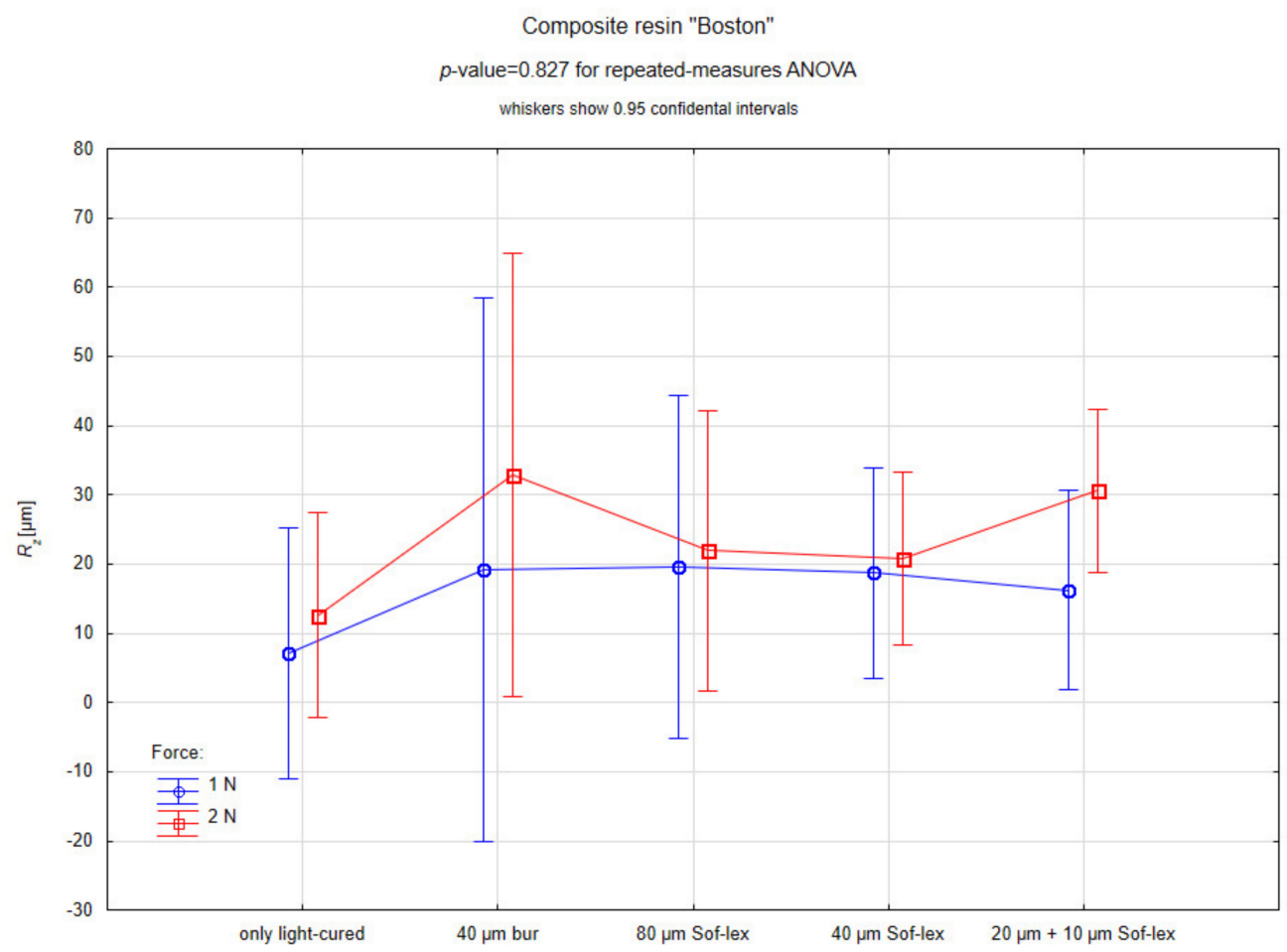

Figure 5. Repeated-measures analysis of variance for $R_{z}$ values in the individual polishing steps depending on the press-on force for Boston samples. 
Table 2. Representative Figures for Optical Profilometry Analysis in the Individual Polishing Steps Depending on the Composite Resin and the Press-on Force.

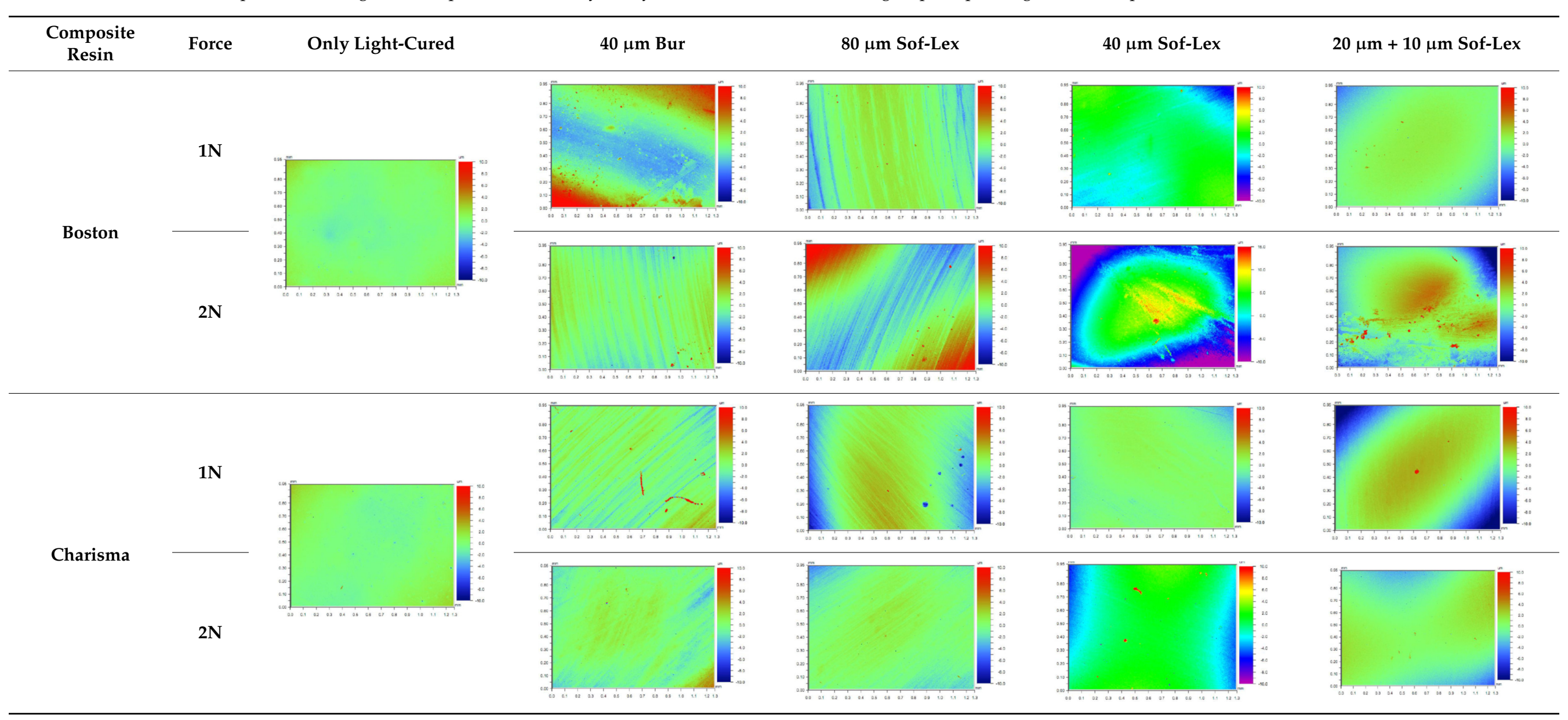


Table 3. Analysis of Values of Selected Indices of Profilometric Examination.

\begin{tabular}{|c|c|c|c|c|c|c|c|c|c|}
\hline & \multirow{3}{*}{$\begin{array}{c}\text { Composite Resin } \\
\text { Force }\end{array}$} & \multicolumn{4}{|c|}{ Boston } & \multicolumn{4}{|c|}{ Charisma } \\
\hline & & \multicolumn{2}{|c|}{$1 \mathrm{~N}$} & \multicolumn{2}{|c|}{$2 \mathrm{~N}$} & \multicolumn{2}{|c|}{$1 \mathrm{~N}$} & \multicolumn{2}{|c|}{$2 \mathrm{~N}$} \\
\hline & & Mean & SD & Mean & SD & Mean & SD & Mean & SD \\
\hline \multirow{5}{*}{$\begin{array}{c}R_{a} \\
{[\mu \mathrm{m}]}\end{array}$} & only light-cured & 0.644 & 0.365 & 0.644 & 0.365 & 0.484 & 0.072 & 0.484 & 0.072 \\
\hline & $40 \mu \mathrm{m}$ bur & 0.939 & 0.184 & 1.097 & 0.218 & 0.960 & 0.274 & 1.185 & 0.620 \\
\hline & $80 \mu \mathrm{m}$ Sof-lex & 0.925 & 0.151 & 2.725 & 2.384 & 1.141 & 0.332 & 1.033 & 0.238 \\
\hline & $40 \mu \mathrm{m}$ Sof-lex & 1.668 & 0.909 & 2.110 & 1.348 & 1.611 & 1.545 & 1.843 & 0.755 \\
\hline & $20 \mu \mathrm{m}+10 \mu \mathrm{m}$ Sof-lex & 1.017 & 0.429 & 2.670 & 1.178 & 1.154 & 0.793 & 1.233 & 0.447 \\
\hline \multirow{5}{*}{$\begin{array}{c}R_{q} \\
{[\mu \mathrm{m}]}\end{array}$} & only light-cured & 0.863 & 0.514 & 0.863 & 0.514 & 0.677 & 0.097 & 0.677 & 0.097 \\
\hline & $40 \mu \mathrm{m}$ bur & 1.230 & 0.209 & 1.570 & 0.483 & 1.390 & 0.311 & 1.680 & 0.741 \\
\hline & $80 \mu \mathrm{m}$ Sof-lex & 1.175 & 0.199 & 3.300 & 2.732 & 1.477 & 0.404 & 1.483 & 0.448 \\
\hline & $40 \mu \mathrm{m}$ Sof-lex & 2.080 & 1.059 & 2.610 & 1.566 & 1.963 & 1.803 & 2.483 & 0.690 \\
\hline & $20 \mu \mathrm{m}+10 \mu \mathrm{m}$ Sof-lex & 1.252 & 0.436 & 3.323 & 1.409 & 1.464 & 1.001 & 1.650 & 0.750 \\
\hline \multirow{5}{*}{$\begin{array}{c}R_{z} \\
{[\mu \mathrm{m}]}\end{array}$} & only light-cured & 12.580 & 9.685 & 12.580 & 9.685 & 21.680 & 4.009 & 21.680 & 4.009 \\
\hline & $40 \mu \mathrm{m}$ bur & 20.773 & 7.919 & 32.820 & 20.034 & 41.263 & 10.386 & 69.923 & 76.428 \\
\hline & $80 \mu \mathrm{m}$ Sof-lex & 20.430 & 7.691 & 21.950 & 11.198 & 21.897 & 14.282 & 103.507 & 137.832 \\
\hline & $40 \mu \mathrm{m}$ Sof-lex & 20.553 & 3.232 & 20.843 & 8.289 & 22.403 & 10.532 & 98.427 & 109.443 \\
\hline & $20 \mu \mathrm{m}+10 \mu \mathrm{m}$ Sof-lex & 16.200 & 1.428 & 30.643 & 7.789 & 10.610 & 6.955 & 73.667 & 93.510 \\
\hline \multirow{5}{*}{$\begin{array}{c}R_{t} \\
{[\mu \mathrm{m}]}\end{array}$} & only light-cured & 26.570 & 26.901 & 26.570 & 26.901 & 40.377 & 1.470 & 40.377 & 1.470 \\
\hline & $40 \mu \mathrm{m}$ bur & 40.230 & 19.952 & 57.300 & 22.914 & 78.297 & 24.722 & 99.717 & 89.397 \\
\hline & $80 \mu \mathrm{m}$ Sof-lex & 51.430 & 23.827 & 41.357 & 23.331 & 33.383 & 21.447 & 153.943 & 199.767 \\
\hline & $40 \mu \mathrm{m}$ Sof-lex & 35.847 & 9.657 & 31.990 & 21.071 & 39.050 & 14.506 & 132.667 & 126.391 \\
\hline & $20 \mu \mathrm{m}+10 \mu \mathrm{m}$ Sof-lex & 39.640 & 4.384 & 49.997 & 16.016 & 20.043 & 10.612 & 94.657 & 110.706 \\
\hline
\end{tabular}

Table 4. Results of Repeated-measures Analysis of Variance for Profilometric Parameters in the Individual Polishing Steps Depending on the Press-on Force ( $p$-values).

\begin{tabular}{cccc}
\hline & All Samples & Boston & Charisma \\
\hline$R_{a}$ & 0.575 & 0.318 & 0.985 \\
$R_{q}$ & 0.541 & 0.307 & 0.966 \\
$R_{z}$ & 0.431 & 0.827 & 0.336 \\
$R_{t}$ & 0.529 & 0.882 & 0.296 \\
\hline
\end{tabular}

\section{Discussion}

In our study, we investigated the effect of pressure force and the different granularity of the polishing system on the degree of polishing of two different composite materials. Efforts were made to recreate a situation that often takes place in a dental office. After the composite reconstruction, the dentist finds excess material and removes it with a diamond drill with a fine embankment. It is known that excess composite in the area of connection with enamel should not be endured with a diamond drill, as this can result in damaging the enamel and composite [22]. Dentists often choose to use an abrasive disc with a granularity of $80 \mu \mathrm{m}$ (contour). Our study showed that this leads to an even greater scratch of the composite surface in Charisma composites than when using a $40 \mu \mathrm{m}$ diamond bur.

Our investigation showed that the smoothest composite samples are those polymerized by Mylar tape. This is confirmed by previous studies by other authors [23-25]. However, clinically, to properly shape the restoration in the mouth, finishing and polishing steps are necessary. In this case, the surface of the composite, even the smoothest, is changed in this process.

The $2 \mathrm{~N}$ force press on to the disc seemed to result in a much higher roughness of the composite than with a force of $1 \mathrm{~N}$. The results of our research correspond to previous analyses that have shown that increased polishing force generates a higher roughness of 
composite fillings $[15,19]$. The increased strength of the press-on has a positive effect on surface smoothness only for ceramic and metal materials [26]. Heintze et al. [18] analyzed the pressure force applied by 10 dentists when polishing composite fillings. The pressure ranges differed significantly but fluctuated at approximately $2 \mathrm{~N}$. It is suggested that the $2 \mathrm{~N}$ force is optimal for polishing composite fillings. Although the differences were not statistically significant, we can see a better visual polishing effect at $1 \mathrm{~N}$. However, a dentist's diagnosis of strength 1, 2 or $3 \mathrm{~N}$ may not be possible. It seems necessary that, at the stage of pre-graduate education, dental students should have a dynamometer at their disposal and be able to perform the polishing procedure under its control. Perhaps this would give some idea of the value of the force used. Until now, dental students have analyzed the pressure force of the dental tool only in the case of a periodontological probe. The so-called 'subnail test' is known, which aims to make students understand the power with which this tool should be used. It is described as the force required to blanch the subnail tissues when the probe is pressed under the thumbnail. The recommended force in this test is $0.25-0.5 \mathrm{~N}$ [27]. However, it does not give an idea of a force of 1 or $2 \mathrm{~N}$. During polishing at 1 and $2 \mathrm{~N}$, the effect of greater wear of polishing surfaces or discs was not visually noticeable.

The abrasive discs used in the test tend to evenly abrase the filler particles and resin matrix, resulting in a smooth surface [14,28]. Not only for composite materials, but the multi-stage abrasive disc polishing protocol also yields favorable results. This is also recommended for resin-modified glass-ionomers [29]. The use of an abrasive disc system for polishing also appears to help control the force used. In our study, a much more frequent bending of the disc was observed from the polished surface at a force of $2 \mathrm{~N}$. Other researchers confirm that more significant pressure is more dangerous for polished surfaces with finishing rubber or burs than for discs $[18,19]$.

Scientific research indicates a significant advantage of nanofilled composites over microfilled and hybrid composites, both in terms of durability and aesthetics. It has been shown that the smaller diameter of the particles, their spherical shape and similar size guarantee the best physical properties. This is due to the fact that the filler particles are packed very closely and the amount of resin in the spaces between the filler is reduced $[30,31]$. In our study, we analyzed the influence of the polishing force on two microfilled composites, used during undergraduate training of dental students. In the Boston composite, a microfiller of similar particle size was used, and in Charisma composite, the difference in the size of the filler particles was significant which could have affected the roughness.

A particular limitation of our work seems to be polishing only a flat imitation of the filling. When polishing fissures and cusps, the polishing force decomposes less linearly. Part of the filling is subject to pressure from the vertical direction, but the slopes of the cusps are under pressure from the force's horizontal or oblique direction. Other technical limitation of the study was that the diameter of the used light guide was $8 \mathrm{~mm}$, while the diameters of the samples were $10 \mathrm{~mm}$.

Indeed, the force of pressure that influences final polishing is not the only factor modifying smoothness. The rotation of the angle, use of water spray and the polishing time must still be taken into account. Importantly, this subject requires further and thorough research to establish a detailed polishing protocol, preferably for each composite material individually. Moreover, the clinical inference regarding plaque accumulation and aesthetic appearance would be desirable.

Further studies are required to confirm our findings.

\section{Conclusions}

The study suggests that the pressure force has an impact on the final result of the polishing process.

1. The higher-pressure force of the individual polishing discs may generate greater roughness of the composite material at each polishing stage. 
2. According to our findings, a force of $1 \mathrm{~N}$ seems to be much more favorable for polishing.

3. A smaller difference in filler diameters in composite material can promote improved polishing.

Author Contributions: Conceptualization and methodology, A.L. and K.N.; formal analysis, K.N.; investigation and resources, A.L., P.S., M.K. and O.C.; writing-original draft preparation, A.L., K.N. and N.P.; writing-review and editing, A.S. and A.R.; visualization, K.N.; supervision, A.S. and A.R.; project administration, A.L. All authors have read and agreed to the published version of the manuscript.

Funding: This research received no external funding.

Institutional Review Board Statement: Not applicable.

Informed Consent Statement: Not applicable.

Data Availability Statement: The data presented in this study are available on request from the corresponding author.

Acknowledgments: The project was implemented with the use of funds for science, awarded by the Poznan University of Medical Sciences. The work was also supported by the Ministry of Science and Higher Education of Poland under Contract No. 16.16.110.663 (AGH University of Science and Technology).

Conflicts of Interest: The authors declare no conflict of interest.

\section{References}

1. Goldberg, M. In Vitro and in Vivo Studies on the Toxicity of Dental Resin Components: A Review. Clin. Oral Investig. 2008, 12, 1-8. [CrossRef] [PubMed]

2. Rogalewicz, R.; Voelkel, A.; Kownacki, I. Application of HS-SPME in the Determination of Potentially Toxic Organic Compounds Emitted from Resin-Based Dental Materials. J. Environ. Monit. 2006, 8, 377-383. [CrossRef]

3. Gupta, S.K.; Saxena, P.; Pant, V.A.; Pant, A.B. Release and Toxicity of Dental Resin Composite. Toxicol. Int. 2012, 19, 225-234. [CrossRef]

4. Schmalz, G.; Cieplik, F. Biofilms on Restorative Materials. Monogr. Oral Sci. 2021, 29, 155-194. [CrossRef]

5. Kurt, A.; Cilingir, A.; Bilmenoglu, C.; Topcuoglu, N.; Kulekci, G. Effect of Different Polishing Techniques for Composite Resin Materials on Surface Properties and Bacterial Biofilm Formation. J. Dent. 2019, 90, 103199. [CrossRef]

6. Aykent, F.; Yondem, I.; Ozyesil, A.G.; Gunal, S.K.; Avunduk, M.C.; Ozkan, S. Effect of Different Finishing Techniques for Restorative Materials on Surface Roughness and Bacterial Adhesion. J. Prosthet. Dent. 2010, 103, 221-227. [CrossRef]

7. Yadav, R.D.; Raisingani, D.; Jindal, D.; Mathur, R. A Comparative Analysis of Different Finishing and Polishing Devices on Nanofilled, Microfilled, and Hybrid Composite: A Scanning Electron Microscopy and Profilometric Study. Int. J. Clin. Pediatr. Dent. 2016, 9, 201-208. [CrossRef]

8. Madhyastha, P.S.; Hegde, S.; Srikant, N.; Kotian, R.; Iyer, S.S. Effect of Finishing/Polishing Techniques and Time on Surface Roughness of Esthetic Restorative Materials. Dent. Res. J. 2017, 14, 326-330. [CrossRef]

9. Radlanski, R.J. A New Carbide Finishing Bur for Bracket Debonding. J. Orofac. Orthop. 2001, 62, 296-304. [CrossRef]

10. Nedeljkovic, I.; De Munck, J.; Vanloy, A.; Declerck, D.; Lambrechts, P.; Peumans, M.; Teughels, W.; Van Meerbeek, B.; Van Landuyt, K.L. Secondary Caries: Prevalence, Characteristics, and Approach. Clin. Oral Investig. 2020, 24, 683-691. [CrossRef] [PubMed]

11. Alhareky, M.; Tavares, M. Amalgam vs. Composite Restoration, Survival, and Secondary Caries. J. Evid. Based Dent. Pract. 2016, 16, 107-109. [CrossRef]

12. Schwendicke, F.; Lamont, T.; Innes, N. Removing or Controlling? How Caries Management Impacts on the Lifetime of Teeth. Monogr. Oral Sci. 2018, 27, 32-41. [CrossRef]

13. Endo, T.; Finger, W.J.; Kanehira, M.; Utterodt, A.; Komatsu, M. Surface Texture and Roughness of Polished Nanofill and Nanohybrid Resin Composites. Dent. Mater. J. 2010, 29, 213-223. [CrossRef] [PubMed]

14. Erdemir, U.; Sancakli, H.S.; Yildiz, E. The Effect of One-Step and Multi-Step Polishing Systems on the Surface Roughness and Microhardness of Novel Resin Composites. Eur. J. Dent. 2012, 6, 198-205. [CrossRef] [PubMed]

15. Pala, K.; Tekçe, N.; Tuncer, S.; Serim, M.E.; Demirci, M. Evaluation of the Surface Hardness, Roughness, Gloss and Color of Composites after Different Finishing/Polishing Treatments and Thermocycling Using a Multitechnique Approach. Dent. Mater. J. 2016, 35, 278-289. [CrossRef]

16. Sapra, V.; Taneja, S.; Kumar, M. Surface Geometry of Various Nanofiller Composites Using Different Polishing Systems: A Comparative Study. J. Conserv. Dent. 2013, 16, 559-563. [CrossRef] [PubMed] 
17. Pettini, F.; Corsalini, M.; Savino, M.G.; Stefanachi, G.; Venere, D.D.; Pappalettere, C.; Monno, G.; Boccaccio, A. Roughness Analysis on Composite Materials (Microfilled, Nanofilled and Silorane) After Different Finishing and Polishing Procedures. Open Dent. J. 2015, 9, 357-367. [CrossRef]

18. Heintze, S.D.; Reinhardt, M.; Müller, F.; Peschke, A. Press-on Force during Polishing of Resin Composite Restorations. Dent. Mater. 2019, 35, 937-944. [CrossRef]

19. Heintze, S.D.; Forjanic, M.; Rousson, V. Surface Roughness and Gloss of Dental Materials as a Function of Force and Polishing Time in Vitro. Dent. Mater. 2006, 22, 146-165. [CrossRef]

20. Kocaagaoglu, H.; Aslan, T.; Gürbulak, A.; Albayrak, H.; Taşdemir, Z.; Gumus, H. Efficacy of Polishing Kits on the Surface Roughness and Color Stability of Different Composite Resins. Niger. J. Clin. Pract. 2017, 20, 557-565. [CrossRef]

21. St-Pierre, L.; Martel, C.; Crépeau, H.; Vargas, M.A. Influence of Polishing Systems on Surface Roughness of Composite Resins: Polishability of Composite Resins. Oper. Dent. 2019, 44, E122-E132. [CrossRef] [PubMed]

22. Barbosa, S.H.; Zanata, R.L.; Navarro, M.F.D.L.; Nunes, O.B. Effect of Different Finishing and Polishing Techniques on the Surface Roughness of Microfilled, Hybrid and Packable Composite Resins. Braz. Dent. J. 2005, 16, 39-44. [CrossRef] [PubMed]

23. Bansal, K.; Gupta, S.; Nikhil, V.; Jaiswal, S.; Jain, A.; Aggarwal, N. Effect of Different Finishing and Polishing Systems on the Surface Roughness of Resin Composite and Enamel: An In Vitro Profilometric and Scanning Electron Microscopy Study. Int. J. Appl. Basic Med. Res. 2019, 9, 154-158. [CrossRef]

24. Ehrmann, E.; Medioni, E.; Brulat-Bouchard, N. Finishing and Polishing Effects of Multiblade Burs on the Surface Texture of 5 Resin Composites: Microhardness and Roughness Testing. Restor. Dent. Endod. 2019, 44, e1. [CrossRef]

25. Senawongse, P.; Pongprueksa, P. Surface Roughness of Nanofill and Nanohybrid Resin Composites after Polishing and Brushing. J. Esthet. Restor. Dent. 2007, 19, 265-273; discussion 274-275. [CrossRef]

26. Da Silva, T.M.; Salvia, A.C.R.D.; Carvalho, R.F.; de Pagani, C.; da Rocha, D.M.; da Silva, E.G. Polishing for Glass Ceramics: Which Protocol? J. Prosthodont. Res. 2014, 58, 160-170. [CrossRef] [PubMed]

27. Al Shayeb, K.N.; Turner, W.; Gillam, D.G. Accuracy and Reproducibility of Probe Forces during Simulated Periodontal Pocket Depth Measurements. Saudi Dent. J. 2014, 26, 50-55. [CrossRef]

28. Kemaloglu, H.; Karacolak, G.; Turkun, L.S. Can Reduced-Step Polishers Be as Effective as Multiple-Step Polishers in Enhancing Surface Smoothness? J. Esthet. Restor. Dent. 2017, 29, 31-40. [CrossRef]

29. Wilder, A.D.; Swift, E.J.; May, K.N.; Thompson, J.Y.; McDougal, R.A. Effect of Finishing Technique on the Microleakage and Surface Texture of Resin-Modified Glass Ionomer Restorative Materials. J. Dent. 2000, 28, 367-373. [CrossRef]

30. De Oliveira, G.U.; Mondelli, R.F.L.; Charantola Rodrigues, M.; Franco, E.B.; Ishikiriama, S.K.; Wang, L. Impact of Filler Size and Distribution on Roughness and Wear of Composite Resin after Simulated Toothbrushing. J. Appl. Oral Sci. 2012, 20, 510-516. [CrossRef]

31. Marghalani, H.Y. Effect of Filler Particles on Surface Roughness of Experimental Composite Series. J. Appl. Oral Sci. 2010, 18, 59-67. [CrossRef] [PubMed] 